\title{
Firewood consumption and extraction from community forests in East Khasi Hills District, Meghalaya: Its impact on woody species diversity and population structure
}

\author{
Marvellous B. Lynser ${ }^{1}$, Ksanbok Makdoh ${ }^{2}$ and Batriti Nongbri ${ }^{1}$ \\ ${ }^{1}$ Department of Environmental Science, Shillong College, Shillong, Meghalaya-793003, India \\ ${ }^{2}$ Department of Botany, Lady Keane College, Shillong, Meghalaya-793001, India
}

*Corresponding Author: mlynser@gmail.com

[Accepted: 13 December 2020]

\begin{abstract}
Firewood serves as the principal source of energy for cooking and heating, for many rural communities, but the impact of firewood extraction on the forest is often undermined. The present study was undertaken to assess the firewood consumption pattern by households living near community forests of East Khasi Hills District, Meghalaya and the impact of such activity on species diversity and population structure on such forests. Data on firewood consumption and preferred firewood species, and impacts of firewood harvesting on species diversity and population structure were collected through household surveys and phytosociological studies respectively. The surveyed households showed high dependency on firewood and the consumption pattern varies with the family size. The preferred firewood species are those of hardwood trees such as Quercus spp., Lithocarpus spp., Castanopsis spp. and Myrica spp. Firewood extraction have negative impact on forests, resulting in decrease in species diversity and population of the preferred firewood species. Statistical analysis revealed that species richness and diversity and density differ significantly in protected and unprotected forests. Despite low per capita consumption of firewood and precautionary measures like regulated harvesting in the study area, firewood harvesting cannot be ignored as an important cause of forest degradation and biodiversity loss. More research into local ecological and cultural contexts and perceptions concerning costs and benefits can help devise sustainable management options, including alternative sources of fuel. Keywords: Firewood harvesting - Local communities - Energy source - Protected forest - Species richness - Biodiversity loss.
\end{abstract}

[Cite as: Lynser MB, Makdoh K \& Nongbri B (2020) Firewood consumption and extraction from community forests in East Khasi Hills District, Meghalaya: Its impact on woody species diversity and population structure. Tropical Plant Research 7(3): 669-677]

\section{INTRODUCTION}

Firewood is an important source of traditional energy for majority of the people in developing countries (San et al. 2012, Specht et al. 2015). Mainly used for food preparation and heating, this energy source is most commonly preferred by people living in mountainous and rural areas chiefly because it is cheap, freely and easily accessible and easy to use (Chettri et al. 2002, Bhatt \& Sachan 2004). Moreover, in such areas due to poor socio-economic conditions, lack of transportation, high prices and limited supply, other forms of commercial energy are beyond the reach of ordinary people (Madubansi \& Shackleton 2007). Majority of India's rural population depends on firewood from natural forests as their principal source of fuel for heating and cooking (Bhatt et al. 2016). Worldwide studies revealed that extensive harvesting of firewood by communities has been exerting pressure on the forests, causing continuous loss of biomass which poses threats to the biological resources in the area and greatly hamper the local economy (Ruger et al. 2008, Specht et al. 2015).

Meghalaya is a hilly state in the Northeastern Region of India with about $80 \%$ of its population living in the rural areas (Anonymous 2017) and 76.3\% of its land under forest cover (FSI 2019). As with majority of the 
north eastern states, Meghalaya too has about ninety percent of its forests under the community control and management (Poffenberger 2007). The local people develop various types of traditional forest management practices which contributed to the conservation of biodiversity and addressing the livelihood needs of the rural people (Tiwari et al. 2010, Tynsong \& Tiwari 2011, Lynser \& Tiwari 2016). Rural households in Meghalaya depend heavily on firewood for cooking and heating purposes (Lynser 2013). A major portion of the firewood for household use comes from community forests, as firewood extraction from government forests is usually restricted. In areas where agro-forestry systems exist, a substantial portion of firewood comes from agro-forests.

Despite the fact that the state has got rich forest resources, rapid increase in population during the past few decades has led to an increase in firewood consumption resulting in the encroachment of forests for firewood. Though a number of studies on firewood consumption and its potential impact on forest biodiversity and structure are available from other parts of the world (Specht et al. 2015, Sassen et al. 2015) and India (Kumar \& Shahabuddin 2005, Shaheen et al. 2016), similar studies are lacking in Meghalaya. The East Khasi Hills, one of the districts in the state has a low forest cover as compared to other districts and has witnessed a decline in the forest cover during the last two decades (FSI 2019). Recently, a number of studies have been carried out in community forests of East Khasi hills of Meghalaya to understand the importance of these forests to the communities' survival (Lynser \& Makdoh 2018), to evaluate the species diversity and structure (Upadhaya 2015), biomass and carbon stock (Chaudhury \& Upadhaya 2016), and also to understand the effect of human disturbance on woody species composition and structure (Mir \& Upadhaya 2017). However, there are no studies on the effect of firewood consumption and extraction from community forests and its impact on woody species diversity and population structure in East Khasi Hills District, Meghalaya. Therefore, the present study was carried out to estimate the household firewood consumption by communities in East Khasi Hills district of Meghalaya. The study also attempts to examine if firewood extraction has any negative impacts on species diversity and structure of the community forests in the district. Understanding the impacts of firewood extraction on forest quality is important as it will assist in forest maintenance and management which will not only meet the energy requirements of the tribal folk but also to maintain the ecological balance in fragile ecosystem of the region.

\section{MATERIALS AND METHODS}

Study area

The East Khasi Hills district of Meghalaya lies approximately between $25^{\circ} 07^{\prime} \& 25^{\circ} 41^{\prime} \mathrm{N}$ latitude and $91^{\circ}$ $21^{\prime} \& 92^{\circ} 09^{\prime} \mathrm{E}$ longitude. It has an area of $2820 \mathrm{~km}^{2}$ and occupies $12.57 \%$ of the total area of the State. As per 2011 census, the district has a population of 8.26 lakh persons living in 1.61 lakh households and $55.6 \%$ of its total population lives in rural villages (Anonymous 2017). About 62.3 percent of the total geographical area is under forest cover (FSI 2019) with forest types ranging from sub-tropical broad leaf to pine forest (Haridasan \& Rao 1985-87). These forests yield a wide variety of timber and non-timber forest products for commercial and subsistence use, contributing a good source of revenue and income to the people of the district (Tynsong \& Tiwari 2011). About $90 \%$ of rural households in the district rely on firewood from the forest for subsistence use (Anonymous 2014). There are three classes of forests in the district- the State Reserved Forests and the State Protected Forests which comprised a very small percentage $(1.04 \%)$ of the total forest cover in the district and the Unclassified Forests (mainly comprising of community forests) which forms a major chunk of the total forest cover. These community forests are managed by the local communities through traditional institutions who develop various traditional forest management practices to ensure sustainability of the forests (Mir \& Upadhaya 2017). These forests are assigned different local names and serve a specific purpose. For example, the Law Adong and Law Kyntang are safety forests, specifically protected for biodiversity conservation, maintaining ecosystem services and the environment, whereas the Law Shnong and Law Raid are supply forests mainly meant to cater the day to day resources needs of the local population (Rodgers 1994)

For the present study, three sites (Dympep, Kyrphei and Wahmawpat) with similar vegetation type and where firewood extraction is done by the local communities were selected for detail analysis. Each site has at least two types of community forest - one which is accessible for firewood extraction by the local communities (referred in this study as unprotected forest - Law Shnong / Law Raid), the other where firewood extraction by local communities is restricted (referred in this study as protected forest - Law Adong) (Fig. 1). The study sites are abbreviated as Dy, Ky and Wa and the forest types Law Shnong as LS and Law Adong as LA.

\section{Data collection}

A preliminary household survey was conducted to assess the firewood dependency on forest and to estimate 
the firewood consumption by households in the study area. Thirty households were randomly selected in each site and with the help of semi-structured questionnaires, quantitative and qualitative data on firewood consumption and harvesting within the area were collected. Firstly, the quantity of firewood consumed per household was estimated by asking the members of the household how many stacks of firewood do they use in a year. One stack approximately contains $1250 \mathrm{~kg}$ of firewood because one stack consists of 30-32 man loads with each load weighing about $40 \mathrm{~kg}$. Secondly, qualitative data such as tree species preferably used for firewood, source, time of collection and household members involved in the collection was collected. Regarding the data on tree species preferably used for firewood, the interviewees were asked to name the tree species most commonly collected by the household for firewood purposes (Specht et al. 2015) and these were rated in a scale of 1 to 3 with 1 as highly preferred firewood species and 3 for low quality firewood species. Key Informant Survey was also carried out with knowledgeable people of different age-groups to acquire information on measures taken to minimize negative impact that firewood harvesting may have on biodiversity and forest in the area.

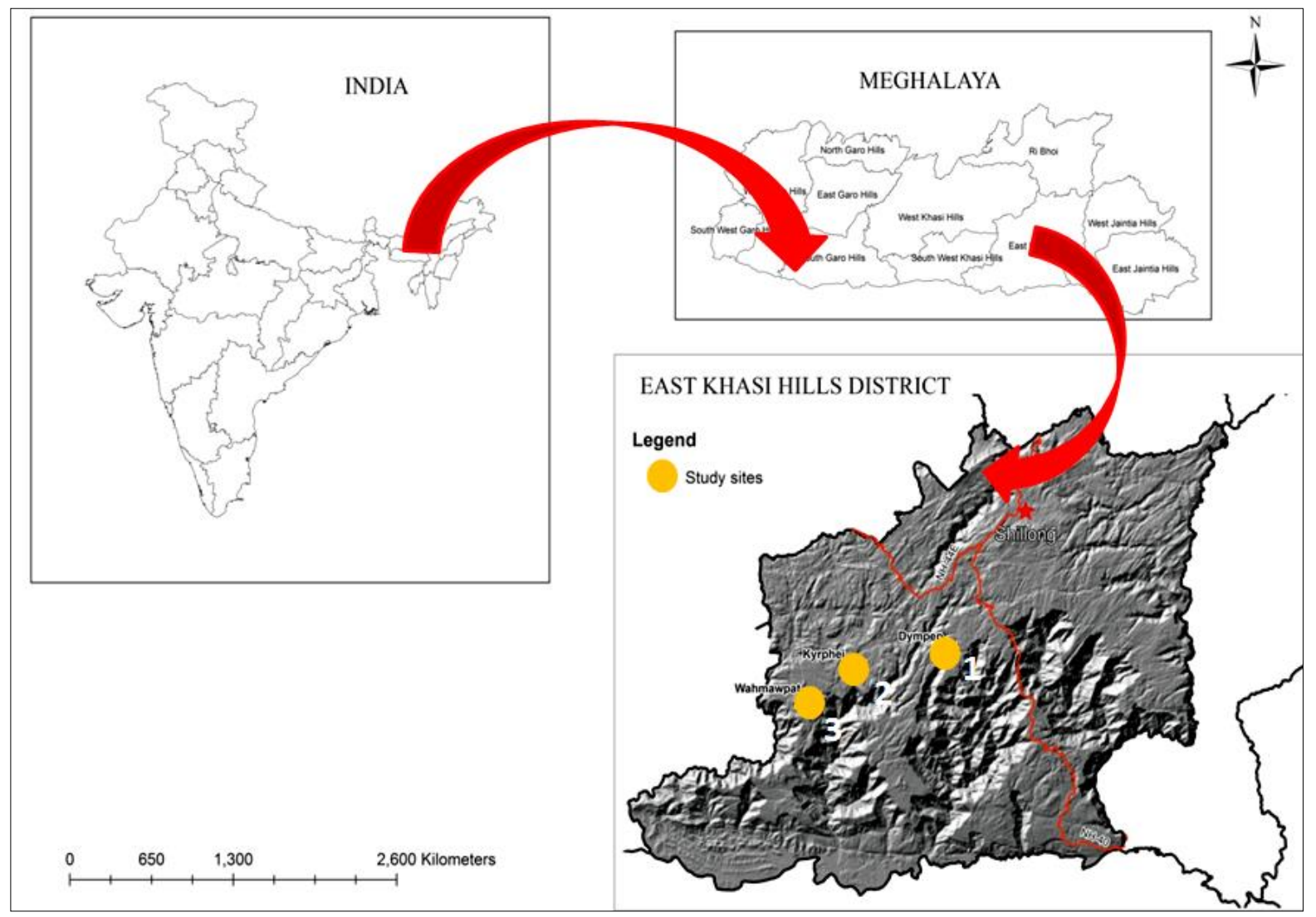

Figure 1. Location map showing the study sites.

To assess the impact of firewood extraction on woody species diversity and population structure, woody species $\geq 20 \mathrm{~cm}$ girth at breast height were sampled using quadrat method in two types of forests: Protected and Unprotected in each of the three sites. Altogether 6 forests were sampled by randomly laying thirty quadrats of $10 \mathrm{~m} \times 10 \mathrm{~m}$ in each forest. Species were identified and densities of woody plants were determined. Trees with multiple stems and connected near the ground were counted as single individual (Ayyappan \& Parthasarathy 1999). Specimens of all species were collected and herbaria were prepared following Jain \& Rao (1977) and identification was done following Flora of Assam (Kanjilal et al. 1934-1940) and Forest Flora of Meghalaya (Haridasan \& Rao 1985-1987). The nomenclatures of the species follows the regional flora. Important community parameters such as frequency, density, basal area and importance value index (IVI) of all the woody plant species were worked out by following Misra (1968) and Muller-Dombois \& Ellenberg (1974). The species richness ' $\mathrm{S}$ ' was obtained by listing all the woody species occurring in the respective forest following Whittaker (1972). The Species richness ' $S$ ' in all the forest was calculated using the formula:

$$
D_{M g}=\frac{(\mathrm{S}-1)}{\log N}
$$

Where, $\mathrm{D}_{\mathrm{Mg}}=$ Margalef's index, ' $\mathrm{S}$ ' is the total number of species occurred and ' $\mathrm{N}$ ' is the total number of individuals of all species. 
The species diversity index $\left(\mathrm{H}^{\prime}\right)$ was determined by using the method given by Shannon \& Weaver (1963):

$$
\mathrm{H}^{\prime}=\sum_{i=1}^{s} \mathrm{p} i \ln p I
$$

Where, $\mathrm{H}^{\prime}=$ Shannon -Weiner diversity index, $p i$ is the proportion of individuals in the $i$ th species i.e. $($ ni/ $/ \mathrm{N})$; $n i=$ importance value index of the species; and $N=$ importance value index of all the species.

To analyze the significance of variations in parameters such as species richness and diversity, stem density and the basal area between the different forest stands $t$ test was done. Significance level $p$ has been given consulting with the critical values of the $t$ distribution (Zar 2004).

\section{RESULTS}

Household firewood consumption

Firewood is an important source of cooking fuel for the households in the study area. More than $98 \%$ of the surveyed households depend on firewood for meeting their basic cooking needs (Table 1). The quantity of firewood collected for self-consumption ranges between 0.63 to 5.0 tonnes per household per year. On average, each household collects about $2.43 \pm 1.08$ tonnes of firewood per year which comes to $0.48 \pm 0.22$ tonnes per person per year. It seems that households with larger family size collects higher amount of biomass for firewood, however when calculated on a per capita basis it is the smaller family size households who consumed more firewood (Table 2). Another observation was that households rearing livestock (especially pig) consumed more firewood. Firewood is collected mainly for subsistence use as large scale sale of firewood from the community forests is banned in the area. However, local sale in a small scale particularly by poor households within the village is allowed.

Table 1. Household firewood consumption in the study area $(\mathrm{N}=90)$.

\begin{tabular}{lrrrrr}
\hline Site & $\begin{array}{r}\text { Total no. } \\
\text { of HH }\end{array}$ & $\begin{array}{r}\text { Percentage of HH } \\
\text { collecting firewood from } \\
\text { community forests }\end{array}$ & $\begin{array}{r}\text { Firewood } \\
\text { consumption } \\
\text { (tones/HH/year) }\end{array}$ & $\begin{array}{r}\text { Collection } \\
\text { intensity (tones / } \\
\text { year) }\end{array}$ & Use value \\
\hline Dympep & 70 & 97 & 2.83 & 198.1 & $\mathrm{~S}, \mathrm{C}$ \\
Kyrphei & 139 & 100 & 1.63 & 226.6 & $\mathrm{~S}, \mathrm{C}$ \\
Wahmawpat & 180 & 100 & 2.82 & 507.6 & $\mathrm{~S}$ \\
\hline
\end{tabular}

Note: *S-subsistence use; C-small scale commercialization, HH-House hold.

Table 2. Household size versus firewood consumption in the study area.

\begin{tabular}{lrrr}
\hline Household size & $\begin{array}{r}\text { Members in a } \\
\text { family }\end{array}$ & $\begin{array}{r}\text { Firewood consumption } \\
\text { (tones/HH/year) }\end{array}$ & $\begin{array}{r}\text { Firewood consumption } \\
\text { (tones/capita/year) }\end{array}$ \\
\hline Large & $>7$ & 3.38 & 0.38 \\
Medium & $4-7$ & 2.48 & 0.41 \\
Small & $1-4$ & 1.73 & 0.52 \\
\hline
\end{tabular}

Tree species used as firewood

On the basis of responses from the surveyed households, the list of tree species preferred as firewood by the local communities is given in table 3. The most preferred tree species as firewood are those belonging to the Fagaceae family like Quercus spp., Lithocarpus spp., Castanopsis spp. and Myrica spp. The next preferred tree species include Elaeocarpus spp., Schima wallichii DC. and Wendlandia wallichii W. \& A. Others like Exbucklandia populnea Griff., Camellia sp., Rhodendron spp., Garcinia spp., Photinia spp. and Eurya accuminata DC. are also good for firewood use but they are not abundant or easily available. Species like Engelhertia spicata Leschen. ex Bl., Aralia aramata (G. Don) Seem., Pinus kesiya Roxb., Helicia nilagirica Bedd., Symplocos spp. are considered not suitable for firewood purpose; only in cases where people do not have any other option then these species are used as firewood. Almost all the surveyed households harvest firewood from the nearby community forests mainly during the dry winter months.

Table 3. Tree species preferred as firewood by the local communities.

\begin{tabular}{llrr}
\hline S.N. & Tree species & $\begin{array}{r}\text { HH collecting } \\
\text { the species }(\%)\end{array}$ & $\begin{array}{r}\text { Preference } \\
\text { Rating }\end{array}$ \\
\hline 1 & Aralia aramata (G. Don) Seem. & 43 & 3 \\
2 & Camellia sp. & 78 & 2 \\
3 & Castanopsis sp. & 100 & 1 \\
4 & Elaeocarpus sp. & 76 & 2 \\
5 & Engelhertia spicata Leschen. ex B1. & 56 & 3 \\
\hline
\end{tabular}




\begin{tabular}{llrl}
\hline 6 & Eurya acuminata DC. & 66 & 3 \\
7 & Exbucklandia populnea Griff. & 61 & 2 \\
8 & Garcinia sp. & 33 & 2 \\
9 & Helicia nilagirica Bedd. & 51 & 3 \\
10 & Lithocarpus sp. & 100 & 1 \\
11 & Myrica sp. & 100 & 1 \\
12 & Persea sp. & 33 & 2 \\
13 & Photinia sp. & 56 & 2 \\
14 & Pinus kesiya Roxb. & 80 & 3 \\
15 & Quercus sp. & 33 & 1 \\
16 & Rhus javanica L. & 50 & 3 \\
17 & Schima wallichii DC. & 98 & 2 \\
18 & Symplocos sp. & 67 & 3 \\
19 & Syzygium tetragonum Wall. ex. Kurz. & 33 & 1 \\
20 & Wendlandia wallichii W. \& A. & 94 & 1 \\
\hline
\end{tabular}

Impact of firewood extraction on woody species diversity and population structure

The vegetation survey revealed that there was a significant difference in species richness and density of trees in the protected and unprotected forest (Table 4). Overall species richness recorded in protected forests (82 species, 61 genera and 40 families) was comparatively higher to the unprotected forests with 52 species, 43 genera and 30 families. The Margalef species richness index differ significantly, it was 6.2 for protected forests while for unprotected forest it was 4.7. Protected forests recorded significantly higher mean tree density (2593 individuals $\mathrm{ha}^{-1}$ ) than unprotected forests (1728 individuals $\mathrm{ha}^{-1}$ ). The dominant tree species on the basis of density in the protected forest are those belonging to Fagaceae family, while the unprotected forests are dominated by species from the Proteaceae family. Similarly, the mean basal area was higher in protected forests $\left(40.68 \mathrm{~m}^{2} \mathrm{ha}^{-1}\right)$ than unprotected forests $\left(21.73 \mathrm{~m}^{2} \mathrm{ha}^{-1}\right)$ (Table 4).

Table 4. Diversity and community characteristics of woody vegetation in Protected and Unprotected forest of East Khasi Hills.

\begin{tabular}{|c|c|c|c|c|c|c|c|c|c|}
\hline \multirow[t]{2}{*}{ Parameters } & \multicolumn{4}{|c|}{ Protected forests } & \multicolumn{4}{|c|}{ Un-protected forests } & \multirow[t]{2}{*}{ Significance } \\
\hline & Dy_LA & Ky_LA & Wa_LA & *Mean & Dy_LS & Ky_LS & Wa_LS & *Mean & \\
\hline $\begin{array}{l}\text { Species } \\
\text { richness }\end{array}$ & 43 & 38 & 46 & $\begin{array}{r}42.3 \\
( \pm 4.04)\end{array}$ & 32 & 25 & 31 & $\begin{array}{r}29.3 \\
( \pm 3.79)\end{array}$ & $11.26^{* * * *}$ \\
\hline $\begin{array}{l}\text { Number of } \\
\text { genera }\end{array}$ & 39 & 27 & 38 & $\begin{array}{r}34.7 \\
( \pm 6.66)\end{array}$ & 30 & 23 & 28 & $\begin{array}{r}27.0 \\
( \pm 3.61)\end{array}$ & $4.13 * *$ \\
\hline $\begin{array}{l}\text { Number of } \\
\text { families }\end{array}$ & 28 & 21 & 25 & $\begin{array}{r}24.7 \\
( \pm 3.51)\end{array}$ & 24 & 22 & 21 & $\begin{array}{r}22.3 \\
( \pm 1.53)\end{array}$ & 1.4 \\
\hline $\begin{array}{l}\text { Margalef's } \\
\text { diversity index }\end{array}$ & 6.1 & 5.5 & 7.1 & $\begin{array}{r}6.2 \\
( \pm 0.82)\end{array}$ & 5.0 & 3.6 & 5.4 & $\begin{array}{r}4.7 \\
( \pm 0.93)\end{array}$ & $6.52 * * *$ \\
\hline $\begin{array}{l}\text { Shannon } \\
\text { index }\end{array}$ & 3.0 & 2.7 & 3.2 & $\begin{array}{r}3.0 \\
( \pm 0.25)\end{array}$ & 2.9 & 2.4 & 2.8 & $\begin{array}{r}2.7 \\
(0.28)\end{array}$ & $3.02 * *$ \\
\hline $\begin{array}{l}\text { Density } \\
\left(\text { stems }^{-1}{ }^{-1}\right)\end{array}$ & 2637 & 2957 & 2187 & $\begin{array}{r}2593.3 \\
( \pm 386.82)\end{array}$ & 1743 & 2580 & 860 & $\begin{array}{r}1727.8 \\
( \pm 860.11)\end{array}$ & $3.15^{* *}$ \\
\hline $\begin{array}{l}\text { Basal cover } \\
\left(\mathrm{m}^{2} \mathrm{ha}^{-1}\right)\end{array}$ & 30.47 & 38.79 & 52.79 & $\begin{array}{r}40.68 \\
( \pm 11.28)\end{array}$ & 18.92 & 32.70 & 13.56 & $\begin{array}{r}21.73 \\
( \pm 9.87)\end{array}$ & 1.88 \\
\hline
\end{tabular}

Note: Results of t tests: $*=\mathrm{p}<0.05, * *=\mathrm{p}<0.1 ; *$ Mean \pm standard deviation.

Species richness, tree density and basal area consistently decreased with increasing girth class from 20 to $140 \mathrm{~cm}$ in both types of forests resulting in a reverse J-shaped curve (Fig. 2). Higher species richness and tree density was observed in protected than unprotected forest for all girth class. The distribution of basal area across different girth class in protected forests decrease with increase in girth class except for girth class 120-140 cm, while in unprotected forests it initially decreases upto the girth class $60-80 \mathrm{~cm}$ and beyond which the basal area was unevenly distributed (Fig. 2).

\section{DISCUSSION}

Majority of the households in the study area rely on firewood for meeting their basic cooking needs, consuming over 2.43 tonnes per household per year. These findings revealed a high dependency of the households in the study area on firewood which is similar to studies registered for other developing tropical countries such as Burma, Nigeria and Cambodia (San et al. 2012, Sein et al. 2015, Iheke \& Osuji 2015). Household dynamics such as average family size and number of households has an influence on the consumption of firewood and smaller family size households consumed more firewood on a per capita basis (Knight \& Rosa 2012). The amount of firewood consumed per capita recorded in this study is lower as www.tropicalplantresearch.com 
compared to similar studies in the region by Chettri et al. (2002) and Bhatt et al. (2016).
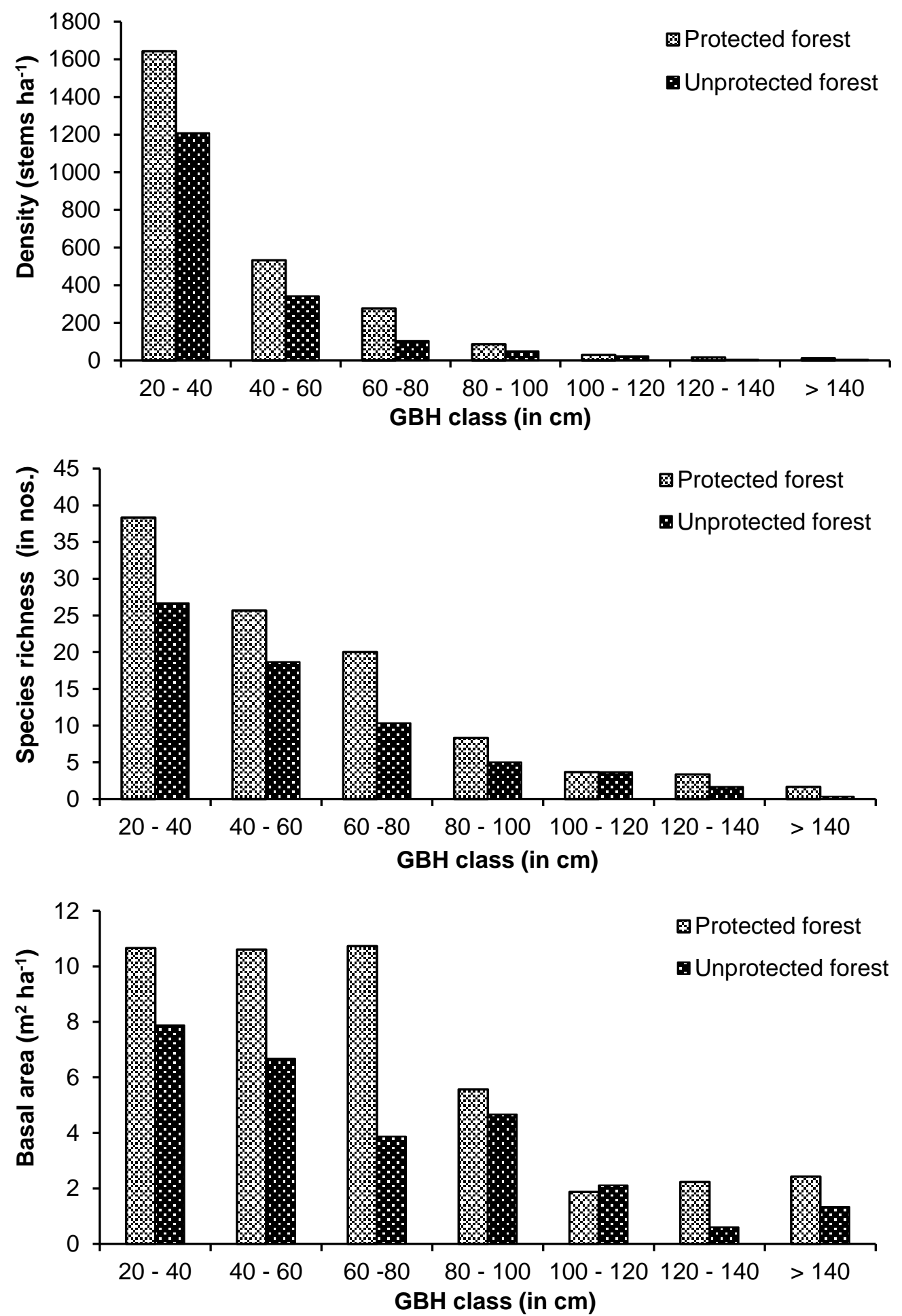

Figure 2. Density (stems ha $\left.{ }^{-1}\right)$, Species richness (in nos), and Basal area $\left(\mathrm{m}^{2} \mathrm{ha}^{-1}\right)$ of woody species in different girth class in protected and unprotected community forests of East Khasi Hills District, Meghalaya, India.

Rural communities possessed good knowledge on woody species for fuelwood use (Ramos et al. 2008). For firewood purpose, Quercus spp. and Lithocarpus spp. are highly preferred as these are hardwood species and they burn for a longer time (Baroody 2013). Other species like Schima spp., Symplocos spp., Elaeocarpus spp and Myrica spp. are of slightly lower quality, but people harvest these as restricting only to tree species from the Fagaceae family may not be sufficient to meet the firewood need of the whole community. Species like Engelhertia spicata, Aralia aramata and Helicia nilagirica are not considered as good firewood as they produce less heat and burn out very fast. Only in situations when the preferred species are not conveniently located, people harvest these species for firewood use. Although available throughout the year, firewood is particularly collected during the winter months (Ramos \& de Albuquerque 2012). During rainy season, the firewoods are www.tropicalplantresearch.com 
wet and heavy and because of the difficult terrain, their transportation is inconvenient. Moreover, firewood is needed year round, so huge quantity is needed to be collected and thus required the involvement of almost all members of the household. Winter months (November-February) are also considered to be the best time for collection as young family members (children) are free from their school schedule.

Human use of bio-resources such as firewood can result in a change in the tree communities (Specht et al. 2015). Tree species richness and density differed significantly in the protected and unprotected forests. The decreased in woody species richness and density in unprotected forests as a result of human activities and firewood harvesting in particular corroborates with studies by Tripathi et al. (2008), Tahoor et al. (2016) and Mir \& Upadhaya (2017). The unprotected forests showed a markedly decrease in density of highly preferred firewood species like Quercus spp., Lithocarpus spp., Castanopsis spp. and increase in non-preferred firewood species such as Helicia nilagirica and Engelhertia spicata. Chopping of trees for firewood purpose can deplete the highly-preferred tree species (Sassen et al. 2015) and species composition shifted to tree species that are not used as fuelwood (Ruger et al. 2008). Our findings is in contrasts to that of Ruger et al. (2008) that with increasing levels of wood extraction, the stem numbers in larger diameter classes decrease whereas there is increase in the stem numbers in smaller diameter classes. This may be due to low harvesting level or that these changes can only be detected after decades or even centuries of repeated disturbance. Different views emerged from researches on implications of wood energy uses over the years. Researchers like Top et al. (2004) and Horst \& Hovorka (2009) opined that wood energy dependence can provide important livelihood opportunities for rural communities and is not likely a significant cause of deforestation, while others like Davidar et al. (2007), Specht et al. (2015) \& Sein et al. (2015) viewed firewood consumption as a major and chronic source of forest degradation. Despite the low per capita consumption of firewood and the presence of regulated harvesting measures in the study area, our results suggest that firewood harvesting cannot be ignored as an important cause of forest degradation and biodiversity loss.

\section{CONCLUSION}

Firewood harvesting in natural forests will continue to remain an important source of energy for the rural population in many developing countries. Our study reflects that even low level extraction with certain precautionary measures can still negatively impact forest structure and biodiversity. It is likely that the demand for fuelwood from natural forests will grow in the foreseeable future leading to intense forest degradation with negative consequences to the people who depend on the forest. More research into local ecological and cultural contexts and perceptions concerning costs and benefits can help devise more sustainable management options, including alternative sources of fuel. A decentralised management approach that builds on local institutions and understandings of the resource can help to maintain the ecological balance in rich but fragile eco-system of the region and poverty amelioration of a large part of human population that still depends directly on forest goods.

\section{ACKNOWLEDGEMENTS}

The authors are grateful to the people of Dympep, Kyrphei and Wahmawpat for sharing their time and knowledge. Thanks to the anonymous reviewers for their constructive suggestions and comments towards improving the manuscript. The authors would also like to acknowledge the University Grants Commission, GOI, (through Minor Research Projects) for providing funds for this study.

\section{REFERENCES}

Anonymous (2014) Census of India 2011. Meghalaya Series-18 Part XII-B District Census Handbook East Khasi Hills Village and Town Wise Primary Census Abstract (PCA) Directorate of Census Operations, Meghalaya. Available from: http://censusindia.gov.in/2011census/dchb/1706_PART_B_DCHB_EAST\%20 KHASI\%20HILLS.pdf (accessed: 26 Aug. 2018).

Anonymous (2017) Biannual Report. Statistical Hand Book Meghalaya 2017. Directorate of Economics \& Statistics Government of Meghalaya, Shillong.

Ayyappan N \& Parthasarathy N (1999) Biodiversity inventory of trees in a large-scale permanent plot of tropical evergreen forest at Varagalaiar, Anamalaias, Western Ghats, India. Biodiversity and Conservation 8: 1533-1554.

Baroody JJ (2013) Firewood Extraction as a Catalyst of Pine-Oak Forest Degradation in the Highlands of Chiapas, Mexico. (M. Sc. Thesis). University of Washington, USA.

Bhatt BP \& Sachan MS (2004) Firewood consumption along an altitudinal gradient in mountain villages of India. Biomass and Bioenergy 2(7): 69-75. 
Bhatt BP, Rathore SS, Lemtur M \& Sarkar B (2016) Fuelwood energy pattern and biomass resources in Eastern Himalaya. Renewable Energy 94: 410-417.

Chaudhury G \& Upadhaya K (2016) Biomass and carbon stock in subtropical broad-leaved forest ecosystem of Meghalaya, Northeast India. International Journal of Ecology and Environmental Sciences 42(2): 125-133.

Chettri N, Sharma E, Deb DC \& Sundriyal RC (2002) Effect of firewood extraction on tree structure, regeneration and woody biomass productivity in a trekking corridor of the Sikkim Himalaya. Mountain Research and Development 22(2): 150-158.

Davidar P, Arjunam M, Mammen PC, Garrigues JP, Puyravaud JP \& Roessingh K (2007) Forest degradation in the Western Ghats biodiversity hotspot: Resource collection, livelihood concerns and sustainability. Current Science 93(11): 1573-1578.

FSI (2019) Biannual Report. State of Forest Report. Forest Survey of India (FSI). Government Publisher of India, Dehra Dun.

Haridasan K \& Rao RR (1985-1987) Forest Flora of Meghalaya Vol 1 \& 2. Bishen Singh and Mahandrapal Singh, Dehradun, India.

Horst GH \& Hovorka AJ (2009) Fuelwood: The "other" renewable energy source for Africa? Biomass and Bioenergy 33(11): 1605-1616.

Iheke OR \& Osuji J (2015) Demand for Fuel Wood and its Substitution Possibilities in Urban Areas of Umuahia Metropolis of Abia State, Nigeria Subject Classification Type (Method/Approach). Journal of Social Sciences Research 7(1): 1213-1218.

Jain SK \& Rao RR (1977) A Handbook of Field and Herbarium Methods. Today \& Tomorrow's Printers and Publishers, New Delhi, 157 p.

Kanjilal UN, Kanjilal PC, Das A \& De RN (1934-1940) Flora of Assam Vol 1-5. Government Press, Shillong.

Knight KW \& Rosa EA (2012) Household dynamics and fuelwood consumption in developing countries: a cross-national analysis. Population and Environment 33: 365-378.

Kumar R \& Shahabuddin G (2005) Effects of biomass extraction on vegetation structure, diversity and composition of forests in Sariska Tiger Reserve, India. Environmental Conservation 32: 248-259.

Lynser MB \& Makdoh K (2018) Provisioning Role of Forest Ecosystems: The Case of Non Timber Forest Products Use from Community Forests of East Khasi Hills District of Meghalaya, India. Journal of Biodiversity Management and Forestry 7: 2.

Lynser MB \& Tiwari BK (2016) Diversity and Utilisation of Floral Non Timber Forest Products by the Communities in Rural Meghalaya, North-East India. Journal of Forest and Environmental Science 32(1): 39-54.

Lynser MB (2013) Forest Products of Raid Saw Symper, Meghalaya and their Contribution to the Livelihood of the People, (Ph. D. Thesis). North-Eastern Hill University, Shillong, India.

Madubansi M \& Shackleton CM (2007) Changes in fuelwood use and selection following electrification in the Bushbuckridge lowveld, South Africa. Journal of Environmental Management 83(4): 416-426.

Mir AH \& Upadhaya K (2017) Effect of traditional management practices on woody species composition and structure in montane subtropical forests of Meghalaya, Northeast India. Journal of Mountain Science 14(8): $1500-1512$.

Misra R (1968) Ecology Work Book. Oxford \& IBH Publishing Co. New Delhi, India, 242 p.

Muller-Dombios DJ \& Ellenberg H (1974) Aims and methods in vegetation ecology. John Wiley and Sons, New York, $547 \mathrm{p}$.

Poffenberger M (2007) Indigenous Forest Stewards of Northeast India - Technical Report. Community Forestry International, Santa Barbara.

Ramos MA, \& de Albuquerque UP (2012) The domestic use of firewood in rural communities of the Caatinga: How seasonality interferes with patterns of firewood collection. Biomass and Bioenergy 39: 147-158.

Ramos MA, de Medeirosa PM, Almeida AL, Feliciano ALP \& de Albuquerque UP (2008) Can wood quality justify local preferences for firewood in an area of caatinga (dryland) vegetation? Biomass and Bioenergy 32: 503-509.

Rodgers WA (1994) The sacred groves of Meghalaya. Man in India 74: 339-348.

Ruger N, Williams-Linera G, Kissling WD \& Huth A (2008) Long-term impacts of fuelwood extraction on a tropical montane cloud forest. Ecosystems 11: 868-881.

San V, Spoann V, Ly D \& Chheng NV (2012) Fuelwood consumption patterns in Chumriey Mountain, Kampong Chhnang Province, Cambodia. Energy 44(1): 335-346. 
Sassen M, Sheil D \& Giller KE (2015) Fuelwood collection and its impacts on a protected tropical mountain forest in Uganda. Forest Ecology and Management 354: 56-67.

Sein CC, Aye ZM \& Razafindrabe BHN (2015) Study on consumption of fuel wood and its impacts to forest resources in Taungyi District. Global Journal of Wood Science, Forestry and Wildlife 3(2): 43-51.

Shaheen H, Azad B, Mushtaq A \& Khan RWA (2016) Fuelwood consumption pattern and its impact on forest structure in Kashmir Himalayas. Bosque 37(2): 419-424.

Shannon CE \& Weaver W (1963) The mathematical theory of communities. University of Illionis Press, Urbana, $117 \mathrm{p}$.

Specht MJ, Pinto SRR, de Albuquerque UP, Tabarelli M \& Melo FPL (2015) Burning biodiversity: Fuelwood harvesting causes forest degradation in human-dominated tropical landscapes. Global Ecology and Conservation 3: 200-209.

Tahoor A, Musavi A \& Khan JA (2016) Biomass extraction impact on vegetation community structure in Kaimur wildlife sanctuary, Uttar Pradesh, India. Tropical Plant Research 3(1): 142-152.

Tiwari BK, Tynsong H \& Lynser MB (2010) Forest management practices of the tribal people of Meghalaya, north-east India. Journal of Tropical Forest Science 22: 329-342.

Top N, Mizoue N, Kai S \& Nakao T (2004) Variation in wood fuel consumption patterns in response to forest availability in Kampong Thom Province, Cambodia. Biomass and Bioenergy 27(1): 57-68.

Tripathi OP, Pandey HN \& Tripathi RS (2008) Effects of human activities on structure and composition of woody species of the Nokrek Biosphere Reserve of Meghalaya, North-East India. Journal of Plant Ecology 32: 73-79.

Tynsong H \& Tiwari BK (2011) Diversity and population characteristics of woody species in natural forests and arecanut agroforests of south Meghalaya, Northeast India. Tropical Ecology 52(3): 243-252.

Upadhaya K (2015) Structure and floristic composition of subtropical broad-leaved humid forest of Cherapunjee in Meghalaya, Northeast India. Journal of Biodiversity Management and Forestry 4: 2.

Whittaker RH (1972) Evolution and measurement of species diversity. Taxon 21(2-3): 213-251.

Zar JH (2004) Biostatistical Analysis, $5^{\text {th }}$ Edition. Prentice-Hall, Inc., New York, 944 p. 